\title{
PENGARUH MODAL SOSIAL TERHADAP TINGKAT KESEJAHTERAAN RUMAH TANGGA PETERNAK: STUDI KASUS PADA KELOMPOK PETERNAK AYAM KAMPUNG NGUDI MULYO, GUNUNGKIDUL
}

\section{THE INFLUENCE OF SOCIAL CAPITAL ON FARM HOUSEHOLD'S WELFARE: CASE STUDY ON NGUDI MULYO NATIVE CHICKEN FARMER'S GROUP IN GUNUNGKIDUL}

\author{
Raden Ahmad Romadhoni Surya Putra*, Bambang Ariyadi, Novita Kurniawati, \\ dan Fransiskus Trisakti Haryadi \\ Fakultas Peternakan, Universitas Gadjah Mada, Yogyakarta, 55281
}

Submitted: 19 January 2017, Accepted: 30 May 2017

\section{INTISARI}

Konsep kebijakan pembangunan peternakan Indonesia pada saat ini telah bergeser dari paradigma pembangunan yang sentralistik menuju pada konsep pembangunan partisipatoris. Konsep partisipatoris secara operasional formal diwujudkan dalam bentuk kelompok-kelompok ternak. Kelompok ternak merupakan perwujudan modal sosial di masyarakat yang penting dalam pembangunan masyarakat peternak khususnya dalam peningkatan kesejahteraan rumah tangga. Penelitian ini bertujuan untuk mengetahui pengaruh modal sosial terhadap tingkat kesejahteraan rumah tangga peternak. Data terkait 61 rumah tangga peternak yang tergabung dalam kelompok ternak ayam Ngudi Mulyo di Gunungkidul dikompilasi pada tahun 2016 untuk dianalisis regresi. Hasil penelitian menunjukkan bahwa modal sosial berpengaruh nyata terhadap tingkat kesejahteraan peternak. Hal ini menunjukkan bahwa konsep kebijakan yang partisipatoris dalam pembangunan peternakan berkontribusi dalam peningkatan kesejahteraan rumah tangga yang berbasis pada persepsi diri tentang kesehatan keluarga, penerimaan, dan pendapatan selain untuk faktor produksi.

(Kata kunci: Kebijakan pembangunan peternakan, Modal sosial, Pembangunan masyarakat, Tingkat kesejahteraan)

\begin{abstract}
Concepts of livestock development policy shifted from centralistic to participatory paradigm. Participatory concept is operationally existed as a forming of farmer's groups. The farmer group itself is a formal existence of social capital that is very important in a community development especially on the household's welfare level. The study aims to know the influence of social capital on farm households' welfare. Data which were related to 61 farmer's households of Ngudi Mulyo group's members, Gunungkidual werecompiled in 2016 and analyzed further with regression. The results showed that social capital significantly affected to the farmer households' welfare. It indicated that participatory model in livestock development policy significantly contributes to the increase of farm household's welfare based on self perception on household's health, revenue, and non production income.
\end{abstract}

(Key words: Community development, Livestock development policy, Social capital, Welfare)

\section{Pendahuluan}

Model pembangunan yang sentralistik telah bergeser pada model pembangunan yang lebih partisipatoris. Model partisipatoris menekankan pada keterlibatan masyarakat sebagai aktor pembangunan (Ife dan Tesoriero, 2008). Keberadaan kelompok- kelompok ternak di dalam pembangunan peternakan merupakan perwujudan dari konsep partisipatoris. Keberadaan kelompokkelompok tersebut diikuti dengan programprogram stimulasi dari pemerintah yang bertujuan untuk meningkatkan kesejahteraan peternak. Rendahnya kesejahteraan dan relatif tingginya tingkat kemiskinan petani

\footnotetext{
* Korespondensi (corresponding author):

Telp. +62 8170428119

E-mail: ahmadromadhoni@ugm.ac.id
} 
merupakan kendala dan masalah yang dihadapi oleh sektor pertanian termasuk juga di dalamnya subsektor peternakan. Secara umum, usaha produksi ternak di Indonesia masih didominasi oleh usaha ternak tradisional di pedesaan (Soedjana, 2005).

Kontribusi sektor pertanian secara umum mencapai cukup besar pada pertumbuhan perekonomian nasional. Namun demikian, mayoritas petani masih dalam kondisi tidak sejahtera. Data menunjukkan bahwa $77 \%$ petani dan peternak di Jawa atau $55 \%$ petani dan peternak secara komulatif di Indonesia termasuk dalam kategori petani gurem (BPS, 2013). Hal ini menunjukkan bahwa tingkat kesejahteraan petani dan peternak masih rendah. Sementara itu, tingkat kesejahteraan seringkali diindikasikan dengan pendapatan sebagai salah satu komponen kesejahteraan. Namun demikian, merujuk pada teori Maslow, semakin tinggi kesejahteraan, kebutuhan-kebutuhan ekonomis sebagai indikator kesejahteraan akan semakin berkurang. Manusia cenderung akan meninggalkan kebutuhan ekonomis menuju motivasi yang lebih sosial (Putra, 2006).

\section{Tingkat kesejahteraan}

Dalam konsep pembangunan masyarakat, kemiskinan dan kesejahteraan dapat dipahami sebagai permasalahan lokalitas yang terkait pada tradisi komunitas tersebut (Van Eijk, 2010). Berdasarkan hal tersebut, pembangunan masyarakat secara partisipatoris mencoba mengurai segala macam permasalahan di dalam masyarakat dengan cara merujuk pada pendekatan lokalitas. Pendekatan ini memberikan ruang pada pengetahuan lokal dan kearifan lokal sebagai tulang punggung pembangunan (Ife dan Tesoriero, 2008). Dalam konteks lokalitas agraris, semakin banyaknya peternak yang bergabung dalam komunitas kelompok ternak dapat dipandang sebagai implementasi modal sosial dalam mewujudkan kemajuan pembangunan masyarakat.

Kesejahteraan merupakan suatu hal yang bersifat subjektif sehingga setiap orang mempunyai pandangan hidup, tujuan hidup, dan cara hidup berbeda-beda (Todaro dan Smith, 2006). Kesejahteraan diukur berdasarkan indikator-indikator ketahan pangan seperti ketersediaan pangan, ketercukupan gizi, ketersediaan akses terhadap bahan pangan hingga pada perilaku rumah tangga (Pinstrup-Andersen, 2009).
Indikator kesejahteraan rumah tangga petani ataupun peternak dapat juga menggunakan nilai tukar petani (NTP) yang mencerminkan rasio antara indeks harga yang diterima dan dibayarkan oleh petani dalam bentuk persentase (BPS, 2013). Kesejahteraan petani dapat diindikasikan dengan status kesehatan, jumlah panen per tahun, dan pengeluaran rumah tangga per kapita per bulan (Yokoyama dan Ali, 2009).

\section{Modal sosial}

Perkembangan konsep modal sosial dimulai sejak pertengahan 1990 (Patrick et al., 2006). Modal sosial dapat dipahami melalui pendekatan, secara khusus tidak ada definisi tentang modal sosial akan tetapi beberapa indikator menunjukkan bahwa modal sosial terdiri dari kelembagaan, kekeluargaan, perilaku, dan nilai-nilai yang mengatur interaksi antar manusia yang berkontribusi secara ekonomi maupun sosial (Grootaert dan Van Bastelaer, 2002).

Modal sosial bukan merupakan entitas yang tunggal tetapi multidimensional yang didefinisikan dengan adanya kelompok, jaringan, norma, dan kepercayaan. Modal sosial juga merupakan modal yang sifatnya sosial tidak seperti aset fisik (teknologi, alat) dan sumber daya manusia (pendidikan, keterampilan) yang sifatnya lebih individual (Grootaert, 2004). Dampak positif dari adanya modal sosial khususnya bagi petani adalah ketersediaan informasi dengan biaya yang murah, adanya fasilitas pengambilan keputusan dan pelaksanaannya, dan terkuranginya perilaku oportunis dari anggota kelompok (Grootaert dan Van Bastelaer, 2002).

Modal sosial yang didefinisikan sebagai kontribusi secara sosial maupun ekonomi dalam kelompok formal di Indonesia berpengaruh secara positif dalam kesejahteraan keluarga. Partisipasi dalam kelompok formal dapat menjadi penentu dalam keberlanjutan usaha peternakan (Haryadi et al., 2014). Modal sosial di Negara berkembang merupakan investasi yang cukup meyakinkan, akan tetapi tetap harus mempertimbangkan dan melibatkan modal fisik dan sumber daya manusia. Kepercayaan dan partisipasi yang tinggi dalam kelompok juga terbukti memberikan kontribusi keuntungan yang lebih besar pada keluarga selain itu pengeluaran keluarga juga akan semakin bertambah secara signifikan (Ashley dan Hussein, 2000). Dalam studi kasus di 
Malaysia, modal sosial yang dimiliki petani berdampak positif pada peningkatan performa dalam bertani dengan adanya relasi antar petani, di sisi lain penguatan modal sosial signifikan dalam mengentaskan kemiskinan, meningkatkan pendapatan, dan kesehatan keluarga (Yokoyama dan Ali, 2009).

Modal sosial memiliki implikasi penting terhadap kesejahteraan, khususnya kesejahteraan keluarga di pedesaan. Peternak di Indonesia yang masih memelihara ternak secara tradisional semua hidup di wilayah pedesaan. Hal ini berarti modal sosial yang mereka miliki berimplikasi pada kesejahteraan keluarga. Kelompok Peternak Ayam Ngudi Mulyo yang berada di Dusun Gobeh, Kelurahan Bendung, Kecamatan Semin, Kabupaten Gunung Kidul merupakan salah satu kelompok ternak yang bertujuan untuk mensejahterakan anggotanya. Kelompok ini telah memiliki prestasi yang cukup membanggakan. Sebagai salah salah satu kelompok yang telah memiliki modal sosial yang cukup mapan maka perlu dikaji pengaruh modal sosial terhadap tingkat kesejahteraan rumah tangga peternak sekaligus mengevaluasi keberadaan kelompok ternak sebagai cerminan dari keberadaan modal sosial di masyarakat. Oleh karena itu, penelitian ini bertujuan untuk mengetahui pengaruh modal sosial terhadap tingkat kesejahteraan rumah tangga peternak.

Keberadaan modal sosial di dalam masyarakat merupakan sesuatu yang nyata. Setiap komunitas masyarakat dipastikan memiliki ciri khas dalam mengatur hubungan antar individu. Modal sosial yang bersifat lokalistik ternyata menjadi sesuatu yang penting dalam melakukan pembangunan manusia yang berkelanjutan melalui pendekatan pemberdayaan partisipatoris. Pembangunan manusia yang bertujuan untuk meningkatkan taraf kehidupan yang lebih baik tentu harus mempertimbangkan berbagai macam faktor. Modal sosial yang merepresentasikan adanya kelompok, partisipasi individu, dan kepercayaan antar individu terbukti berpengaruh positif pada kesejahteraan keluarga. Modal sosial juga harus mempertimbangkan adanya modal fisik berupa perlengkapan produksi dan sumber daya manusia berupa pendidikan dan ketrampilan. Perkembangan kelompok ternak pada saat ini merupakan fenomena yang menarik untuk dikaji. Keberadaan modal sosial, aset fisik, dan sumber daya manusia yang dimiliki oleh para peternak juga perlu dipelajari untuk melihat sejauh mana kondisi itu berpengaruh pada kesejahteraan peternak melalui indikator berupa status kesehatan, penerimaan keluarga dalam satu tahun, dan pengeluaran per kapita di luar untuk produksi. Oleh karena itu, dapat diambil hipotesis bahwa modal sosial berpengaruh terhadap tingkat kesejahteraan rumah tangga peternak dengan memasukkan faktor aset fisik dan aset sumber daya manusia sebagai variabel kontrol.

\section{Materi dan Metode}

\section{Materi}

Materi yang digunakan adalah peternak yang tergabung dalam kelompok ternak Ngudi Mulyo, Dusun Gobeh, Kelurahan Bendung, Kecamatan Semin, Kabupaten Gunung Kidul. Kelompok ternak ini telah memiliki banyak prestasi dan memiliki kegiatan kelompok yang aktif. Seluruh anggota kelompok yang berjumlah 61 rumah tangga peternak dilibatkan sebagai responden penelitian.

\section{Metode}

Pengambilan data dilakukan dengan cara sensus dengan cara melibatkan seluruh anggota kelompok menjadi responden pada penelitian ini. Proses pengambilan data menggunakan wawancara tatap muka langsung berdasarkan daftar pernyataan yang ada di kuesioner pada seluruh anggota kelompok. Data mengenai modal sosial dan persepsi yang telah dikumpulkan akan ditabulasi dan dikonversikan dalam bentuk skor (Yokoyama dan Ali, 2009).

\section{Analisis hasil}

Data-data yang telah didapat akan ditabulasi dianalisis menggunakan analisis regresi linear berdasarkan model yang telah ditetapkan. Analisis regresi tersebut menggunakan software MS Excel tahun 2007. Data-data mengenai responden akan dianalisis secara deskriptif. Model penelitian dapat diterjemahkan dalam model matematis yaitu (Yokoyama dan Ali, 2009) :

$$
Y=\alpha+\beta_{1} X_{1}+\beta_{2} X_{2}+\beta_{3} X_{3}+e
$$

\footnotetext{
Keterangan:

Y : Tingkat kesejahteraan rumah tangga peternak

$\alpha \quad$ : Konstanta
} 
$X_{1} \quad$ : Variabel modal sosial

$\beta_{1}$ : Koefisien variabel modal sosial

$X_{2}$ : Variabel aset fisik

$\beta_{2} \quad$ : Koefisien variabel aset fisik

$X_{3}$ : Variabel aset sumber daya manusia

$\beta_{3}$ : Koefisien variabel sumber daya manusia

e : error

\section{Batasan operasional}

Penelitian ini bermaksud hanya untuk menguji pengaruh antara tiga variabel independen terhadap satu variabel dependen. Variabel independen terdiri dari modal sosial, aset fisik, dan aset sumber daya manusia. Variabel dependen yaitu tingkat kesejahteraan rumah tangga peternak. Untuk mempermudah pengambilan data maka disusun indikator-indikator sebagai berikut : 1) modal sosial (skor) antara lain: keikutsertaan anggota keluarga dalam kegiatan kemasyarakatan, partisipasi dalam keanggotaan organisasi, lama keikutsertaan dalam organisasi kelompok ternak, level partisipasi dalam kelompok ternak, persepsi terhadap peran kelompok ternak, tingkat kepercayaan di dalam kelompok; 2) aset fisik (rupiah) antara lain: jumlah ternak yang dimiliki, lahan pertanian yang digarap, aset sumber daya manusia (tahun), tingkat pendidikan, pengalaman beternak; 3) tingkat kesejahteraan rumah tangga peternak (skor) antara lain: persepsi tentang status kesehatan keluarga, persepsi tentang penerimaan keluarga, perspesi tentang pendapatan selain untuk faktor produksi.

\section{Hasil dan Pembahasan}

\section{Gambaran umum karakteristik responden}

Responden yang digunakan dalam penelitian ini berjumlah 61 responden. Responden ini terdiri dari para anggota kelompok ternak Ngudi Mulyo Dusun Gobeh, Kelurahan Bendung, Kecamatan Semin,
Kabupaten Gunung Kidul. Karakteristik responden dapat dilihat pada Tabel 1.

Responden yang dilibatkan dalam peneilitian ini adalah sebagai mereka yang menjadi kepala keluarga. Hal ini dimaksudkan bahwa segala keputusan keluarga adalah tanggung jawab kepala keluarga. Tabel 1 menunjukkan bahwa dari 61 orang responden rata-rata memiliki 4,59 anggota keluarga yang meliputi istri, anak maupun anggota keluarga lain yang tinggal dalam satu rumah. Keikutsertaan para responden dalam kelompok rata-rata telah mencapai 2,72 tahun walaupun tidak semua responden ikut serta dalam keanggotaan kelompok ternak Ngudi Mulyo.

Data yang didapatkan menunjukkan bahwa semua responden memelihara hewan ternak. Tabel 1 juga menunjukkan bahwa ternak yang dipelihara terdiri dari 3 jenis yaitu unggas, sapi, kambing atau domba. Kepemilikan unggas oleh responden rata-rata mencapai 38,45 ekor, kepemilikan sapi ratarata mencapai 1,68 ekor, dan kepemilikan kambing/domba mencapai 3,52 ekor. Kepemilikan ternak ini juga didukung kepemilikan lahan oleh responden yang mencapai 0,59 Ha per keluarga. Kepemilikan lahan dan ternak ini merupakan indikator utama atas aset fisik yang dimiliki oleh responden.

Tabel 1 juga menunjukkan bahwa pengalaman beternak responden rata-rata telah mencapai 19,70 tahun. Hal ini menunjukkan bahwa pengalaman responden dalam memelihara ternak sudah cukup lama. Kondisi ini mengindikasikan bahwa kualitas sumber daya manusia (SDM) peternak jika dilihat dari pengalaman mereka dalam memelihara ternak dapat dipercaya.

Tabel 2 menunjukkan tingkat pendidikan responden. Mayoritas responden memiliki tingkat pendidikan setara SD atau SR yaitu mencapai $68,85 \%$ atau sejumlah 42 responden. Jumlah responden yang lulus

Tabel 1. Karakteristik responden (characteristics of respondents)

\begin{tabular}{lc}
\hline \hline \multicolumn{1}{c}{ Parameter (parameters) } & Rerata (average) \\
\hline Jumlah anggota keluarga (household members) & 4,59 orang (person) \\
Keikutsertaan dalam kelompok (group membership) & 2,72 tahun (years) \\
Kepemilikan unggas (poultry ownership) & 38,45 ekor (head) \\
Kepemilikan sapi (cattle ownership) & 1,68 ekor (head) \\
Kepemilikan kambing/domba (goat/sheep ownership) & 3,52 ekor (head) \\
Kepemilikan lahan (land ownership) & 0,59 hektar (hectar) \\
Pengalaman beternak (raising livestock experience) & 19,70 tahun (years) \\
\hline Sumber (source): data primer (primary data).
\end{tabular}
Sumber (source): data primer (primary data). 
Tabel 2. Tingkat pendidikan (level of education)

\begin{tabular}{lcc}
\hline \hline \multicolumn{1}{c}{ Parameter (parameters) } & Jumlah (number of respondents) & $\%$ \\
\hline Lulus SD/SR (accomplishing elementary school) & 42 & 68,85 \\
Lulus SMP (accomplishing junior high school) & 12 & 19,67 \\
Lulus SMA/SMK (accomplishing senior high school) & 7 & 11,47 \\
Jumlah (total) & 61 & 100,00 \\
\hline
\end{tabular}

Sumber (source): data primer (primary data).

Tabel 3. Hasil analisis regresi

(regression analysis result)

\begin{tabular}{lccccc}
\hline \hline \multicolumn{1}{c}{ Variabel bebas (independent variables) } & $\beta$ & $\mathrm{t}$ & $\mathrm{N}$ & $\mathrm{R}$ Square & $\mathrm{F}$ \\
\hline Modal sosial (social capital) & 0,358 & $4,680^{* *}$ & 61 & 0,324 & $9,114^{\star *}$ \\
Aset fisik (physical asset) & 0,595 & $2,465^{* *}$ & & & \\
Aset SDM (human resource asset) & 0,18 & 0,79 & & & \\
Konstanta (constant) & 0,490 & & & & \\
${ }^{* *}$ signifikan pada P<0,05 (significant at $\mathrm{P}<0.05$ level). & & & & \\
Sumber (source): data primer (primary data). & & &
\end{tabular}

SMP sebanyak 12 orang atau mencapai $19,67 \%$ dan yang lulus SMA/SMK mencapai $11,47 \%$ atau sebanyak 7 orang. Tabel 2 menunjukkan bahwa kualitas SDM responden relatif rendah, ini didasarkan dari pendidikan formal yang mereka ikuti. Hal ini menjadi gambaran umum mengenai keterbatasan akses informasi yang mereka butuhkan.

\section{Pengaruh modal sosial terhadap tingkat kesejahteraan}

Hasil uji regresi linear terhadap variabel-variabel penelitian yaitu modal sosial, aset fisik, dan aset SDM menunjukkan bahwa modal sosial dan aset fisik berpengaruh signifikan terhadap tingkat kesejahteraan responden $(P<0,05)$. Hasil uji regresi ini membuktikan bahwa modal sosial memiliki pengaruh positif secara signifikan pada tingkat kesejahteraan peternak. Partisipasi peternak di dalam kelompok dan tingkat saling percaya antar anggota kelompok berkontribusi secara positif pada tingkat kesejahteraan. Hal ini mengkonfirmasi bahwa modal sosial berpengaruh secara signifikan terhadap tingkat kesejahteraan keluarga (Yokoyama dan Ali, 2009). Modal sosial merupakan perwujudan dari dinamika sosial di dalam komunitas berupa rasa saling percaya (kepercayaan, trust), keikutsertaan dalam organisasi, partisipasi aktif di dalam organisasi, dan persepsi positif terhadap komunitas. Hal ini dapat diterjemahkan bahwa modal sosial merupakan komponen penting dalam peningkatan tingkat kesejahteraan yang merupakan ekspresi dari motif sosial individu-individu di dalam komunitas. Selain itu, pembangunan pertanian secara umum saat ini diarahkan pada konsep demand driven yang mensyaratkan partisipasi peternak dan modal sosial dalam kelompok (Agunga dan Putra, 2015).

Selain proses dinamika kelompok yang diterjemahkan sebagai modal sosial, aset fisik berupa kepemilikan ternak dan lahan memiliki pengaruh penting terhadap tingkat kesejahteraan. Kepemilikan sumber daya berupa ternak dan lahan merupakan indikator faktor produksi. Kepemilikan lahan menunjukkan kapasitas produksi peternak terkait dengan kebutuhan pakan maupun pangan untuk keluarga. Kepemilikan ternak dapat mengindikasikan tabungan dari keluarga. Aset fisik merupakan faktor produksi yang dapat dihitung produktivitasnya untuk menunjang pendapatan keluarga, sehingga aset fisik merupakan salah satu aspek penting untuk mendukung keberlanjutan pembangunan (sustainable development) (Ashley dan Hussein, 2000).

\section{Kesimpulan}

Kajian mengenai pengaruh modal sosial terhadap kesejahteraan peternak menunjukkan bahwa modal sosial secara akumulatif berpengaruh nyata terhadap tingkat kesejahteraan peternak. Oleh karena itu, dinamika sosial di dalam kelompok masyarakat seperti partisipasi individu dan tingkat kepercayaan merupakan indikator penting bagi sebuah modal sosial yang berpengaruh pada tingkat kesejahteraan. Selain itu aset fisik berupa jumlah ternak dan kepemilikan lahan juga terbukti secara nyata berpengaruh pada tingkat kesejahteraan 
peternak. Aspek modal sosial dan aset fisik terbukti memegang peranan penting dalam peningkatan kesejahteraan peternak dalam kebijakan pembangunan peternakan secara partisipatoris.

\section{Daftar Pustaka}

Agunga, R. and R. Putra. 2015. Training Needs of Indonesian Agricultural Extension Workers for the 21st Century: A recommendation based on a field study. Asian J. Agriculture and Development 12: 45-57.

Ashley, C. and K. Hussein. 2000. Developing methodologies for livelihood impact assessment: Experience of the African Wildlife Foundation in East Africa. ODI Working Paper 129. London: ODI.

BPS. 2013. Agricultural statistic based on census 2013 No. 2013. BPS, http://st2013.bps.go.id/dev2/index.php/ site/index.

Grootaert, C. 2004. Measuring social capital: An integrated questionnaire. World Bank Publications.

Grootaert, C. and T. Van Bastelaer. 2002. Understanding and measuring Social Capital. Analysis: 1-320.

Haryadi, F. T., B. Guntoro, E. Sulastri, R. A. Romadhoni, and S. Andarwati. 2014. The effectiveness of farmers' group functions in creating self-sustain of beef cattle farming activities. In: $16^{\text {th }}$ AAAP Animal Science Congress, 10-14 November 2014, Gadjah Mada University, Yogyakarta.
Ife, J. dan F. Tesoriero. 2008. Alternatif Pengembangan Masyarakat di Era Globalisasi. Community Development, Pustaka Pelajar, Yogyakarta, Indonesia.

Patrick, I., G. Marshall, I. Muktasam, and A. Ambarawati. 2006. Determining the role of social capital in linking smallholders with agribusiness. Dalam: 50th annual conference of the Australian agricultural \& resource economic society, Manly Pacific Hotel, Sydney, Australia.

Pinstrup-Andersen, P. 2009. Food security: definition and measurement. Food Security 1: 5-7.

Putra, R. A. R. S. 2006. Motivasi untuk mengkonsumsi protein hewani pada guru Sekolah Menengah Atas di Kota Yogyakarta. Buletin Peternakan 30: 154-160.

Soedjana, T. D. 2005. Prevalensi usaha ternak tradisional dalam perspektif peningkatan produksi ternak nasional. Jurnal Litbang Pertanian 24: 11.

Todaro, M. P. dan S. C. Smith. 2006. Ekonomi Pembangunan. Erlangga, Jakarta.

Van Eijk, G. 2010. Does living in a poor neighbourhood result in network poverty? A study on local networks, locality-based relationships and neighbourhood settings. J. Housing Built Environ. 25: 467-480.

Yokoyama, S. and A. K. Ali. 2009. Social capital and farmer welfare in Malaysia. Japan Agricultural Research Quarterly 43: 323-328. 